\title{
The Innovative Learning of Social Arithmetic using Realistic Mathematics Education Approach
}

\author{
Winda Rahayu, Rully Charitas Indra Prahmana*, Afit Istiandaru \\ Universitas Ahmad Dahlan, Jl. Pramuka No. 42, Pandeyan, Umbulharjo, Yogyakarta, Indonesia \\ *rully.indra@mpmat.uad.ac.id
}

\begin{abstract}
Learning mathematics has a significant contribution to the students' daily activities, one of which is on social arithmetic topic. The implementation of social arithmetic, in general, is mostly found in buying-selling and banking activities. However, students still find difficulties in understanding this topic. It is because the teaching and learning activities still use a conventional approach, which restricts the students to imagine how it is implemented in daily life. Therefore, this paper aims to describe the innovative learning activities of social arithmetic among junior high school students using the Realistic Mathematics Education (RME) approach. This research was conducted in three meetings, and the researcher acted as the teacher in the class. The results showed that the innovative learning of social arithmetic using the RME approach and word problems could improve the students' learning outcomes with an average score of $81.92 \%$ and $92.59 \%$ of the total of students scored above passing grade.

Keywords: innovative learning, junior high school, learning outcomes, realistic mathematics education, social arithmetic
\end{abstract}

Received: October 29, 2020 / Accepted: December 12, 2020 / Published Online: December 13, 2020

\section{Introduction}

Students often complain about mathematics as a challenging and boring subject because of most mathematics teachers ineffective unusual teaching methods, which is then difficult to understand (Chao, Chen, Star, \& Dede, 2016; Albadi, Harkins, \& O’Toole, 2019). Furthermore, Retnawati et al. (2017) asserted that the abstract nature of mathematics objects causes many students to experience difficulties in learning mathematics. Therefore, many students cannot understand mathematics mostly because of its abstractness and meaningless objects, as well as the tedious teaching method.

In mathematics learning, there is a social arithmetic material that discusses the buying and selling activities (Risdiyanti, Prahmana, \& Shahrill, 2019). This material is significant for students to learn because it is closely related to daily life. Furthermore, the application of the concept of social arithmetic in real life is often found mainly in the case of buying and selling (Fauzan, Armiati, \& Ceria, 2018). Since the social arithmetic material is closely related to daily life, then students need to understand it. 
Social arithmetic is generally encountered in buying, selling, and banking activities (Abadi, Pujiastuti, \& Assaat, 2017; Fauzan et al., 2018). The problems presented in social arithmetic are usually word problems that are considered more difficult compared to the other types of issues (Kempert, Saalbach, \& Hardy, 2011). This is because students are required to understand and to solve the problems, as well as to interpret the solutions (Liskala et al., 2011). Also, word problems are significant for students' life because they contain issues that are relevant to daily life, such as learning profit, loss, gross, net, and many more (Jupri \& Drijvers, 2016). Thus, word problems are also useful for students to exercise their thinking abilities and to strengthen their mastery of mathematical concepts.

However, in reality, students still find it difficult to understand social arithmetic material, which generally takes the form of word problems (Vilianti, Pratama, \& Mampouw, 2018; Kurnia \& Retnowati, 2019). For instance, the word problems related to selling price, buying price, gross, net, tare, discount, interest rate, and tax. The difficulties were mostly because the learning method used was speech, while it was hard for the students to imagine how it is implemented in daily life (Fägerstam \& Grothérus, 2018). On the other hand, there is a learning approach that uses everyday life contexts and focuses on students' activities to reinvent and build their knowledge in problemsolving, namely the Realistic Mathematics Education (RME) approach (Tanujaya, Prahmana, \& Mumu, 2017; Fauzan et al., 2018). The RME is based on Freudhental's philosophy (1987), which states that mathematics is a human activity and must be connected to reality. This philosophy underlies the implementation of several studies related to RME that used the context of daily activities as a starting point in learning mathematics (Risdiyanti et al., 2019; Kowiyah, Mulyawati, \& Umam, 2019; Risdiyanti \& Prahmana, 2020). Therefore, in this study, the RME approach is used to solve these social arithmetic learning problems.

As the learning process was designed based on the realistic mathematics education approach, it needed to reflect the three main principles of RME, namely guided reinvention, didactical phenomenology, and emergent models (Gravemeijer, 1994; 1999; Fauzan, Plomp, \& Gravemeijer, 2013). The guided reinvention principle was applied to sequence the learning trajectory to learn social arithmetic topics as intended based on the RME point of view. The second RME principle was realized by using contextual problems as the starting point so that the pupils would experience the process of horizontal and vertical mathematization (Gravemeijer, 1999). The contextual issues would also help the students use their models (model of) to solve the problems until they emerge into a formal way to solve a mathematical problem (model for). 
One of the contexts in the RME approach is using activities that are close to students as a starting point in classroom learning (Laurens et al., 2017; Revina \& Leung, 2019). These activities are parts of the RME approach implemented in the social arithmetic learning process to improve students' learning outcomes. We described the learning process that supports the increase in students' understanding of social arithmetic material.

The next section of this article tells about the research methods used in collecting and analyzing the data. Furthermore, the results and discussion section describe the stages of learning divided into three meetings. At each meeting, several activities are using the RME approach with several contexts that are close to daily life. At last, the results of the study show that the implementation of innovative learning using RME gives significant results in students' learning outcomes, and their summaries are written in the conclusion section.

\section{Method}

This research is a qualitative descriptive study that aims to describe the innovative learning of social arithmetic using the RME approach. The procedures in this research were divided into three stages, namely, preparation, implementation, and analysis. In the preparation stage, we prepared all research instruments, starting from the learning observation sheet, lesson plan using the RME approach, and student worksheet. We also consulted the tools to the school teacher and supervisor as the experts. In the implementation stage, teacher conducted the learning process in three meetings with every meeting consist of 100 minutes. Then, the data analysis stage was carried out after the data collection process. The process of drawing conclusions referred to the results of observations, the student works, learning activities, and the results of the final evaluation of learning.

This research was conducted at one of Muhammadiyah Junior High School, a private Islamic junior high school in Sleman regency, Yogyakarta, Indonesia, from January to February 2019. We involved the seventh-grade students in the even semester of the 2018/2019 school year as the research subjects who have not studied algebra. They were all students of class VII-A, with 28 students consisting of 17 male students and 11 female students. We used two meetings for social arithmetic learning using the RME approach and one meeting for evaluation. The object of this research is the innovative learning of social arithmetic using the RME approach.

The data collection techniques used in this research were documentation, observation, and test. We conducted documentation techniques by capturing the students' activities in the form of photos and video recordings. The video recordings show the activities and strategies of students in solving problems in the classroom. In the process, we used two cameras-first, a static camera to 
document all activities in the classroom. Second, a dynamic camera for recording certain activities such as group discussions among students and question and answer sessions between students and teachers. The observations made during the learning process took place. The activities were carried out based on the observation sheet. The test instrument in this study was a written test. The test aims to determine the students' learning outcomes after participating in the innovative learning of social arithmetic using the RME approach.

Data analysis was performed after the data collection process. The process of concluding refers to the results of observations and students' work. Data analysis conducted in this study compared the effects of views and the supporting data during the learning implementation. Furthermore, we described the implementation process based on the observation sheets and supporting data such as documentation and tests. The students' learning outcomes were reviewed based on the students' test results. The analysis of test results was obtained by checking the students' answers and scoring. After that, a scan of the students' test results was analyzed. As additional information, the minimum completeness criteria of mastery learning for junior high schools in Indonesia, mainly used at SMP Muhammadiyah 1 Mlati, was 75.

\section{Results and Discussion}

The description of the research implementation is described in two major stages, namely the preparation stage and the implementation stage, based on the planned research procedures.

\section{Preparation Stage}

Based on the plan at the preparation stage, we asked the principal of the school to permit us to conduct the research. Then, we conducted an informal interview with the school principal to gather the information needed in conducting the research. The data is about the mathematics learning process in the classroom, the schedule of mathematics learning in one week, the research subject, and the time of the research implementation. In the session, the principal also told the mathematics teacher about our research plan. From the interview, we obtained information that the average number of students in a class was 28-30 students. There were three classes, namely class VIIA, VIIB, and VIIC. We asked for advice from the school to choose the class for the research subjects, and we got the opportunity to teach in class VIIA. This selection was based on the reason that the students of class VIIA had better emotions and behavior. It was essential to make sure that we would not encounter difficulty to adapt to the students in learning mathematics (Mundia, 2017). We also conducted interviews with 
mathematics teachers in class VII to find out what was needed when researching class VIIA. Furthermore, the teacher looked at research instruments we have prepared, such as the lesson plan, observation sheets, and student worksheets. Then finally, the teacher asked us to teach in this study.

Before interviewed with the mathematics teacher, we asked for opinions and suggestions from the supervisor about the research instruments. The supervisor suggested to improve improving in the lesson plan and the questions in the worksheet based on the RME approach. In general, the research preparation plan can be seen in Table 1.

Table 1. The Research Preparation Agenda

\begin{tabular}{ll}
\hline \multicolumn{1}{c}{ Day/Date } & \multicolumn{1}{c}{ Activity } \\
\hline Friday, January 11, 2019 & $\bullet$ Consultation about a learning plan \\
Tuesday, January 15, 2019 & • Consultation about student worksheet \\
Friday, January 18, 2019 & • Consultation about observation sheet \\
Tuesday, January 22, 2019 & • Manage research permit at SMP Muhammadiyah 1 Mlati \\
& • Research preparation consultation with school teachers \\
\hline
\end{tabular}

\section{Implementation Stage}

After the lesson plan, student worksheets, and evaluation tests were validated by the supervisor and also have been discussed with the mathematics teacher, we researched class VIIA. The research process was carried out during three meetings held on 30 January to 1 February 2019. The following is a schedule for conducting research reported in Table 2.

Table 2. Research Schedules

\begin{tabular}{|c|c|}
\hline Day/Date & Activity \\
\hline $\begin{array}{l}\text { Wednesday, January } 30 \text {, } \\
2019\end{array}$ & $\begin{array}{l}\text { - Determining profits if the buying and selling prices are known } \\
\text { - Determining losses if the buying and selling prices are known } \\
\text { - Determining the percentages of profit and losses } \\
\text { - Working on student worksheet } 1\end{array}$ \\
\hline $\begin{array}{l}\text { Thursday, January 31, } \\
2019\end{array}$ & $\begin{array}{l}\text { - Establishing gross, net, and tare if two elements are known } \\
\text { - Determining the percentages of interest rate } \\
\text { - Determining the amount of discount } \\
\text { - Determining the amount of tax } \\
\text { - Working on student worksheet } 2\end{array}$ \\
\hline Friday, February 1, 2019 & - Working on student worksheet three as the final evaluation \\
\hline
\end{tabular}

\section{The First Meeting}

At this first meeting, it consisted of four activities. First, the teacher explained the content about determining profits if buying and selling prices are known. Second, determining the loss if the buying and selling prices are known. Third, determining the percentage of profit and loss. 
And last, working on Students' Worksheet 1 about the profit and loss material. These objectives were conveyed at the beginning of learning. Furthermore, we distributed the Students' Worksheet 1 and grouped the students in seven groups consisting of 4 students each, as shown in Figure 1.

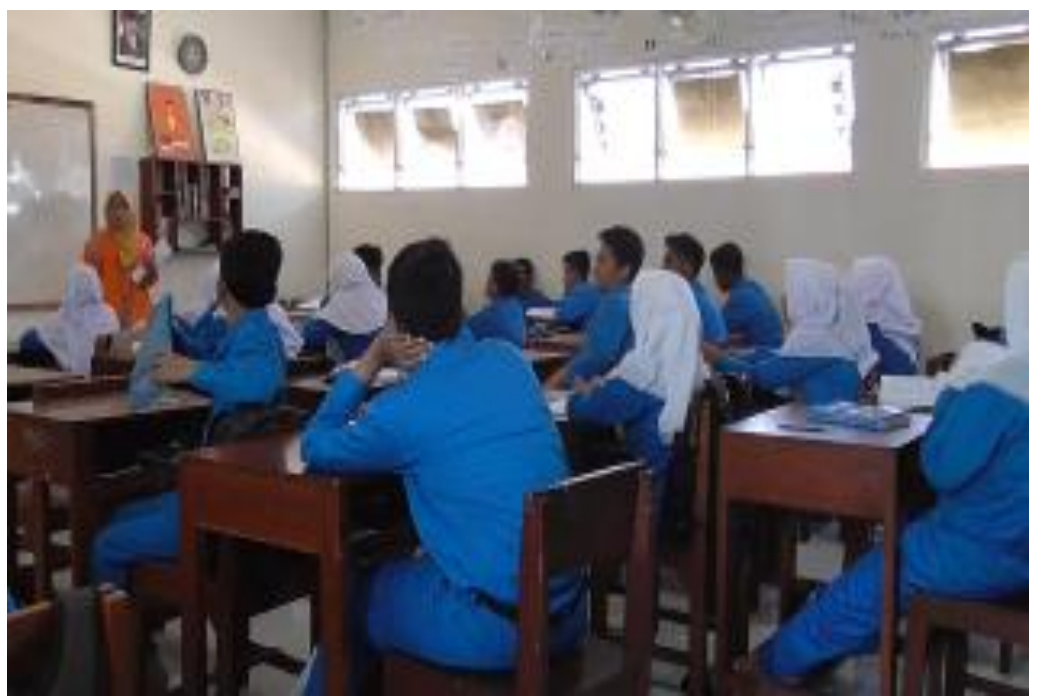

Figure 1. The teacher distributed the Students' Worksheet 1 and grouped the students

After paying attention to the task contained in the student worksheet one about activities in the market, the teacher tried to ask the students. The conversation between teacher and students is reported in Dialogue 1.

Dialogue 1

Teacher: Kira- kira dari foto di atas, aktivitas apa saja yang ada di sana? [From the photo above, what are the activities illustrated there?]

Student: Kegiatan jual dan beli [Buying and selling activities]

Teacher: Ya benar, dari gambar tersebut, ibu dan anak itu sebagai apa? Dan ibu yang satunya lagi sebagai apa? [Yeah, correct. From the picture, what is the role of the woman and the child? And, what is the role of the other woman?]

Student: Ibu dan anak sebagai pembeli dan ibu satunya lagi sebagai penjual. [The first woman and her child as the buyers and the other woman as the seller]

Teacher : Benar sekali, dari kegiatan jual beli biasanya menghasilkan apa? [That's correct. From the buying and selling activities, what is usually the output?]

Student: Untung dan rugi [Profit and loss]

Teacher : Ya benar, apa itu untung dan rugi? Ada yang tahu? [That's correct. What is profit and loss? Does anyone know?

Student: Kalau untung, ibu tersebut mendapat kan uang banyak, kalau rugi tidak dapat uang [If profit, the women gets a lot of money, if loss, she does not get money]

Student: Kalau untung, jualan ibunya habis, kalau rugi, jualan ibunya bersisa [If profit, the women's product sale runs out, if loss, some products unsold] 
Dialogue 1 describes that students can find out what activities are on the market such as buying and selling activities, and they understand that when more and more people buy the women's product, she will make a profit, and vice versa. Furthermore, the teacher explained about determining the benefit and loss, if the buying price and selling price are known. Finally, the teacher told me how to determine the percentage of profit and loss.

Next, the teacher asked students to work on Students' Worksheet 1 by discussing with their respective groups. Students were asked to analyze various ways that can be used to solve the problems in the Students' Worksheet 1, and then students wrote the answers to the issues given. The teacher allowed asking questions if there were still unclear things. Furthermore, the following is a description of the three activities at the first meeting.

\section{Determining the Profit if the Buying and Selling Prices are Known}

The purpose of this activity was to make the students understand what profit is and how to determine if the buying and selling prices are known. Also, students were expected to understand the concept of benefit. Through this first activity, students also found strategies in seeking profits.

Figure 2 shows that the students were asked to compare the buying and selling prices and determined the profit. We provided the buying price, the selling price, and also some instructions. The use of this model is another characteristic of RME because it was related to daily activities.

\section{PROBLEM 2:}

The school shop bought 1 box of mineral water consisting of 48 cups with the price of IDR 14,000. The mineral water was then sold with the price of IDR 500 for a cup. Compare the buying price and the selling price, then calculate the profit the shop earned!

Figure 2. Problem 2 in Students' Worksheet 1

Figure 3 shows that Group 1 finished Problem 2 by finding the total sales price by multiplying the unit price of a cup of mineral water with 48 cups in 1 box to determine the selling price. After getting the total selling price of 1 box of mineral water, they subtracted it with the initial buying price of 1 box of mineral water and got the sale profit. 


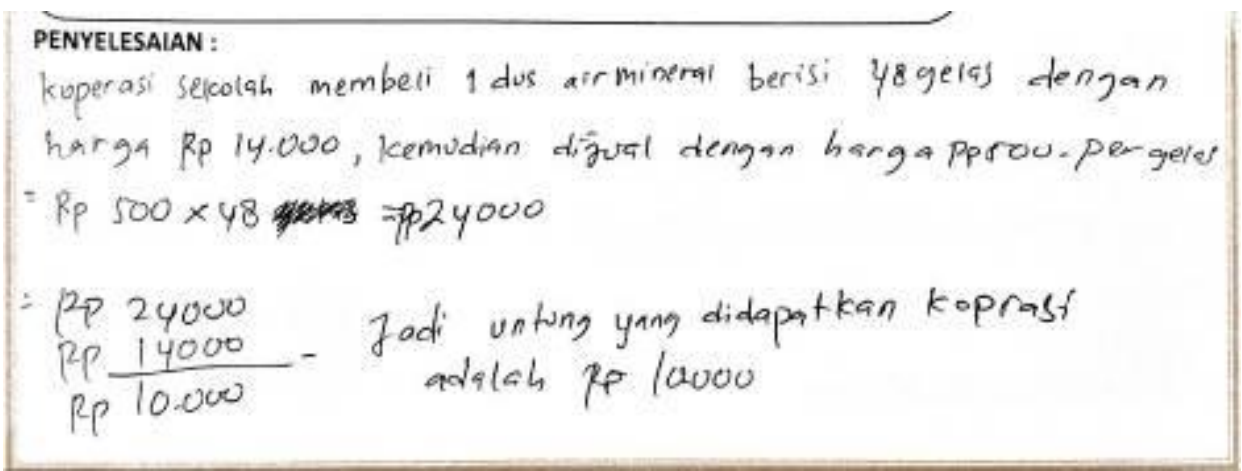

\section{SOLUTION:}

The school shop bought 1 box of mineral water consisting of 48 cups with the price of IDR 14,000. The mineral water was then sold with the price of IDR 500 for a cup.

$=$ IDR $500 \times 48=$ IDR 24,000

$=$ IDR 24,000

IDR $14,000-$

IDR 10,000

Thus, the profit earned by the school shop was IDR 10,000.

Figure 3. Group 1's answer to solving Problem 2

Next, a discussion process took place between the group and the teacher, as described in Dialogue 2. Students were doing construction with the teacher to solve Problem 2.

Dialogue 2

Student: Bu, berarti ini langkah awalnya mencari harga jual nya dulu ya bu? [Ma'am, the first step is finding the selling price first, isn't it?]

Teacher: Iya benar, terus bagaimana lagi? [That's correct, then what else?]

Student: Setelah dapat harga jual tadi terus dikurangi dengan harga belinya bu, lalu dapatlah untung nya bu? [After getting the selling price, then subtract it with the buying price, then we get the profit. Is it true?]

Teacher: Iya kira-kira seperti itu, ayo coba dikerjakan saja. [Yes, something like that, let's just do it.]

Student: Baik bu [Yes ma'am]

In this problem, most of the groups have understood the problems about how to determine the profit and what steps should be taken to find it. In Problem 2, there was one group carelessly made an error in solving the problem due to failure in understanding the problem.

\section{Determining the Loss if the Buying and Selling Prices are Known}

The purpose of this activity was to make the students understand what loss is and how to determine if the buying and selling prices are known. Also, students were expected to understand 
the concept of loss. Through this first activity, students also found strategies in finding loss in different ways by using the problem shown in Figure 4.

\section{PROBLEM 3:}

To pay his school tuition fee, Wawan sells newspaper. One day, he bought 50 exemplars of newspaper with the price of IDR 2,000 each. Because of the rain, he could only sell 30 exemplars in the morning. The remaining exemplars were then sold in the afternoon with the price of IDR 1,500. After being calculated, Wawan suffered loss. How much was the loss?

Figure 4. Problem 3 in Students' Worksheet 1

Figure 4 shows that Wawan sold newspapers on a rainy day, and then students were asked to determine how much his loss when selling newspapers. The use of this model is another characteristic of RME that related to daily life. Furthermore, Figure 5 shows the Group 1 's answer in solving the problem. Group 1 solved Problem 3 by multiplying the money obtained in the afternoon by the number of newspapers sold during the afternoon, which is IDR 30,000, then multiplying the money obtained in the morning with the newspaper sold in the morning, obtained IDR 60,000. Next, students added the morning income and the afternoon income to total revenue of IDR 90,000. Lastly, the capital was reduced by the total income. The Wawan got a loss of IDR 10,000.

\section{SOLUTION:}

Capital: IDR 100,000.

The number of newspapers sold in the morning was 30 pcs.

The number of newspapers sold in the afternoon was 20 pcs.

The money got in the afternoon was IDR 1,500.

IDR $1,500 \times 20=$ IDR 30,000

The money got in the morning was IDR 2,000.

IDR $2,000 \times 30=$ IDR 60,000

IDR $30,000+$ IDR $60,000=$ IDR 90,000

IDR $100,000-$ IDR $90,000=$ IDR 10,000

Thus, the loss was IDR 10,000

Figure 5. Group 1's answers to solve Problem 3

Another answer is shown in Figure 6. As shown in Figure 6, Group 3 worked by multiplying the newspaper obtained from the agent with the unit price of the newspaper, the total cost of the newspaper sale is accomplished. Then, multiplying newspaper sales in the afternoon with the unit price of newspapers obtained total newspaper sales in the morning is IDR 60,000. Next, multiplying the remaining 20 newspaper sales with the afternoon newspaper sales price to get IDR 30,000. Then, adding total morning sales and afternoon sales to get IDR 90,000. Lastly, total sales are subtracted from the capital and get a loss of IDR 10,000. 


\section{SOLUTION:}

Capital: IDR 100,000

In the morning $=30 \times$ IDR 2,000

$$
=\text { IDR } 60,000
$$

$$
\begin{aligned}
& \text { Capital }=\text { IDR } 100,000 \\
& \text { Income }=\text { IDR } 90,000- \\
& \hline \text { Loss }=\text { IDR } \quad 10,000
\end{aligned}
$$

In the afternoon $=20 \times$ IDR $1,500=$ IDR 30,000

Income $\quad=$ IDR $60,000+$ IDR $30,000=$ IDR 90,000

Figure 6. Group 3's answers to solve Problem 3

From Problem 3 in Students' Worksheet 1, all groups have understood the problem of how to determine loss and what steps should be taken. This is evidence from many students' answers in solving the questions given.

\section{Determining the Percentage of Profit and Loss}

Material about determining the percentage of profit and loss is shown from the next problem, as shown in Figure 7. The purpose of this activity is to make students understand the concept of profit and loss and how to find a percentage of them. The rate of profit used to determine the sale profit from a spent capital and the percentage of damage used to determine the sale loss from a contributed capital. Through this activity, students also found strategies in finding the percentage of profit and rate of failure in different ways.

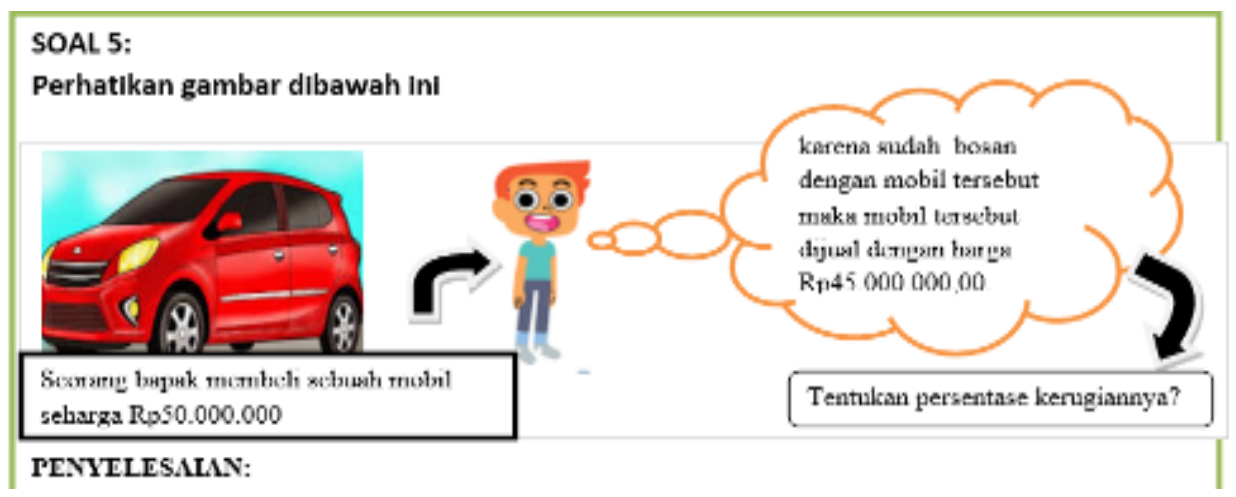

\section{PROBLEM 5:}

Look at the picture below.

A man bought a car with the price of IDR 50,000,000.

Since he was bored with the car, he sold it with the price of IDR 45,000,000.

Determine the percentage of loss he got.

Figure 7. The percentage of profit and loss problem 
Figure 7 shows that students were asked to determine the percentage of loss. The use of this problem is another implementation of RME. Group 1 solved the problem by finding the difference between the buying and selling price, as shown in Figure 8.

$$
\begin{aligned}
& \text { Car with a price of IDR 50,000,000, } \\
& \text { sold with the price of IDR 45,000,000 } \\
& =\frac{5000000}{50000000} \times 100 \% \\
& =\frac{5}{5 \theta} \times 10 \theta \%=\frac{50}{5}=10 \% \\
& \text { IDR 50,000,000 } \\
& \text { IDR 45,000,000- } \\
& \text { IDR } 5,000,000
\end{aligned}
$$

Figure 8. Group 1's answer to Problem 5

In Figure 8, Group 1 got IDR 5,000,000 difference from the buying price and the selling price, which was the loss. Then, they divided it by the selling price of the car and multiplied by one hundred percent to get the percentage of the loss. Thus, the rate of the loss was 10 percent. Furthermore, Group 5 and Group 7 did not work according to the instruction and did not write any information, either. They just calculated the loss without the percentage, as shown in Figure 9.

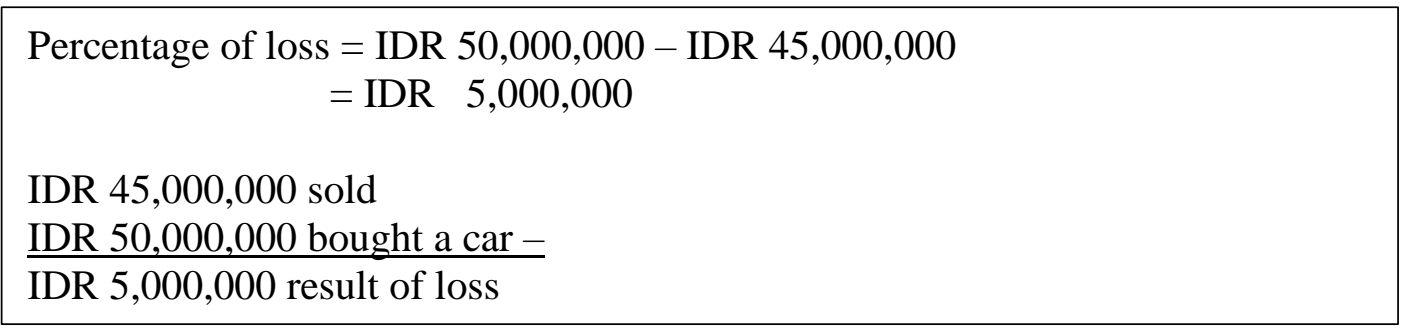

Figure 9. The answer to Problem 5 by Group 5 and 7

There was also Group 6, who solved the Problem 5, directly finding the percentage of loss without providing how to find the loss, as presented in Figure 10. Group 6 directly wrote the loss divided by the buying price times 100 percent and got $10 \%$.

$$
\begin{aligned}
P R & =\frac{R}{1-13} \\
& =\frac{5.000000}{50000000} \times 100 \% \\
& =\frac{5}{5} \times 10 \\
& =\frac{50}{5} \\
& =10 \%
\end{aligned}
$$$$
\begin{gathered}
P R(\text { percentage of loss })=\frac{R(\text { loss })}{H B(\text { buying price })} \\
=\frac{5,000,000}{50,000,000} \times 10 \theta \% \\
=\frac{5}{5} \times 10 \\
=\frac{50}{5} \\
=10 \%
\end{gathered}
$$

Figure 10. Group 6's answer to Problem 5 
In Problem 5, most of the groups have understood the problems about how to look for the loss and the percentage of loss, though some groups did not follow the instruction and have not finished. It can be seen that students were still not careful enough and were not accustomed to reading the instructions carefully. Therefore, students were still confused in solving the given problems. Besides, in Problem 2 and Problem 5, some students did not understand how to determine profit/loss and the percentage of profit/loss. Some students must be guided by the teacher to follow it through an illustration that the teacher provided by reminding how profit earned and how the loss happened. Finally, all students could solve the problems with the teacher's guidance.

The students who could complete the worksheet correctly got rewards in the form of "good", "smart", and "very good" predicate from the teacher. The teacher asked the groups' representatives to present their answer in front of the class. At the end of the first meeting, we still found some errors.

\section{The Second Meeting}

The second meeting began with praying, checking the students' attendance, reminding to the previous material, conveying the learning objectives, and delivering content to the students. At this meeting, there were four activities, namely explaining a single interest, teaching about the net, gross, and tare, explaining tax, and working on Worksheet 2 in groups.

The teacher grouped the students in groups consisting of 3-4 students. Then, the teacher distributed Worksheet 2 and guided the students to work on it. The activity began by discussing the places to learn the material, as presented in Figure 11.

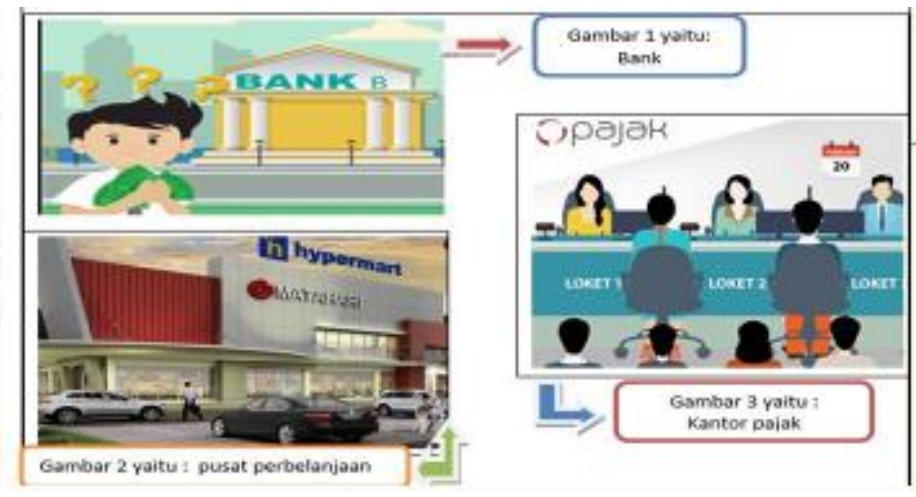

The first picture is bank.

The second picture is supermarket.

The third picture is tax office.

Figure 11. Places related to the material in the second meeting 
The first place was a bank to learn about a single interest. The second place was a supermarket to learn about the net, gross, tare, and discount, as shown in Figure 12.

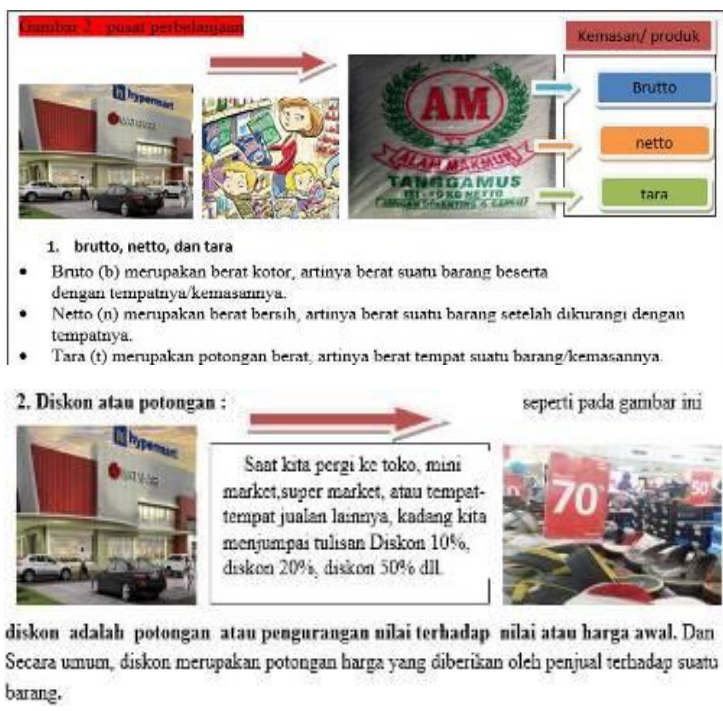

\section{Gross, net, and tare}

- Gross is weight of goods with the container.

- Net is the weight of goods without the container.

- Tare is the weight of the empty container.

\section{Discount}

- When we go to supermarket, we often find many posts of Discount $10 \%, 20 \%, 50 \%$, and so on.

- Discount is a reduction from the initial price of a product given by the seller.

Figure 12. Gross, net, tare, and discount understanding

The last place introduced to students was the tax office. In this activity, the teacher used the tax office context to explain taxes and how to determine taxes, as shown in Figure 13.
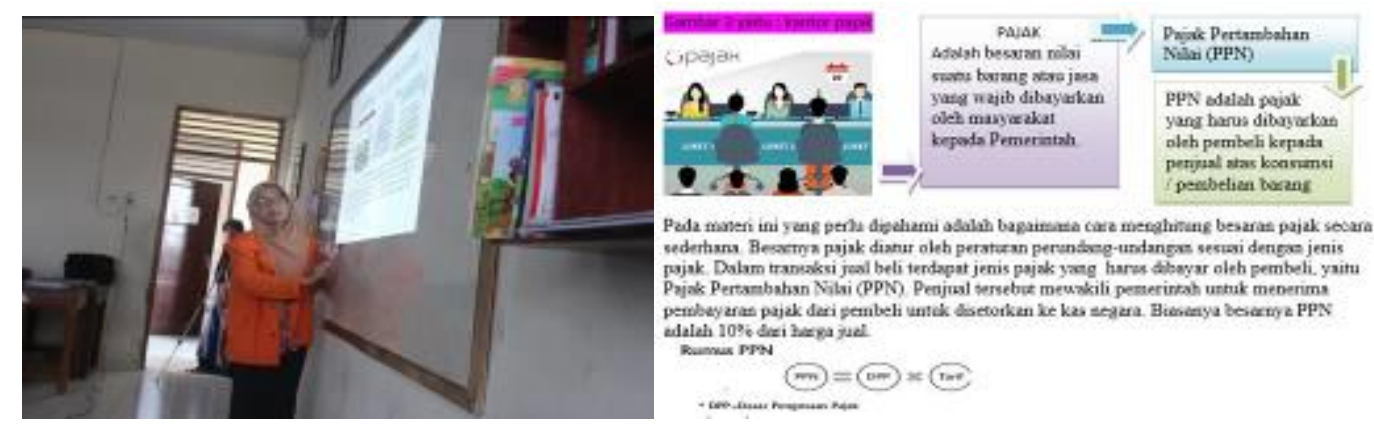

Tax is an amount of money which has to be paid to government based on the value of goods or services.

Value added tax (VAT) is a tax for consuming or buying a goods or service. In this material, students need to understand how to calculate tax in simple way. The amount of tax is regulated by law based on the kinds of taxes. In buying and selling transaction, buyer needs to pay added value tax (VAT). The seller represents the government to receive the tax and then transfer it to the government reserve. The amount the VAT is $10 \%$ of the selling price.

Figure 13. The teacher explains about taxes

After the students have the same perception related to the material, the teacher asked the students to work on Worksheet 2. The teacher reminded them to understand the problems and be more careful in working on Worksheet 2. Furthermore, students discussed with each group and analyzed the issues in Worksheet 2 in various ways. At the same time, the teacher went 
around the classroom to see the results of the students' work and invited them to ask if they found difficulty in solving problems. The following is a description of the three activities at the second meeting.

\section{Determining Single Interest}

The method of determining a single interest was implemented by working on the problems in Worksheet 2, as shown in Figure 14. The purpose of this activity is to make students understand what a single interest is and how to determine it. Also, the students were expected to understand the concept of individual interest. Through this activity, students also found a strategy in seeking different single attention in each group.

\section{Problem 1}

Mother borrows some money from a bank of IDR 4,500,000 at 30\% of interest rate per year. She borrowed it for 5 years. Calculate the amount of the interest for the 5 years and how much money she has to pay.

Figure 14. Problem 1 of Worksheet 2

In Figure 15, students were asked to calculate the amount of interest for five years and how much money should be paid by the mother. The use of this model is another characteristic of RME, which is related to daily life.

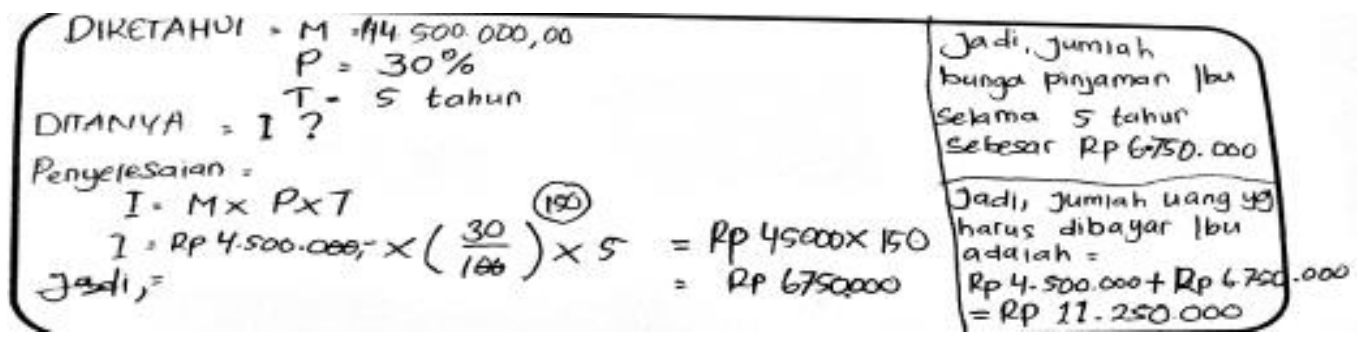

$$
\begin{aligned}
\text { GIVEN: } \quad \mathrm{M}=\mathrm{IDR} 4,500,000 \\
\mathrm{P}=30 \% \\
\mathrm{~T}=5 \text { years }
\end{aligned}
$$

GOAL: $\quad \mathrm{I}=$ ?

Solution :

$$
\begin{aligned}
& \mathrm{I}=\mathrm{M} \times \mathrm{P} \times \mathrm{T} \\
& \mathrm{I}=\mathrm{IDR} 4,500,000 \times \frac{30}{100} \times 5=I D R 4,500,000 \times 150 \\
& =6,750,000
\end{aligned}
$$

The amount of tax for 5 years was IDR 6,750,000

The amount of money should be paid by mother was IDR 4,500,000 + IDR $6,750,000=$ IDR $11,250,000$

Figure 15. The answer to Problem 1 of Worksheet 2 Group 1 
The results of Group 1's answers explained the amount of interest for five years and how much money should be paid by the mother with $\mathrm{M}$ as the money borrowed by the mother, $\mathrm{P}$ as the interest rate, $T$ as the term of the loan, then $I$ as the amount of interest, as shown in Figure 15. They substituted the formula I, which is $\mathrm{M} \times \mathrm{P} \times \mathrm{T}$, to get the results. Then, the result of I added with $\mathrm{M}$ to get the total loan amount that must be paid by the mother for five years is IDR $11,250,000$. They finished by providing information and working in sequence according to the existing formula. These results are the same as the answers given by the other groups, except Group 4.

Group 4 had a different answer from the other groups. Group 4 stated that to calculate the amount of interest for five years and how much money the mother must pay. The detail is presented in Figure 16. The total obtained in this group was very different from the other groups.

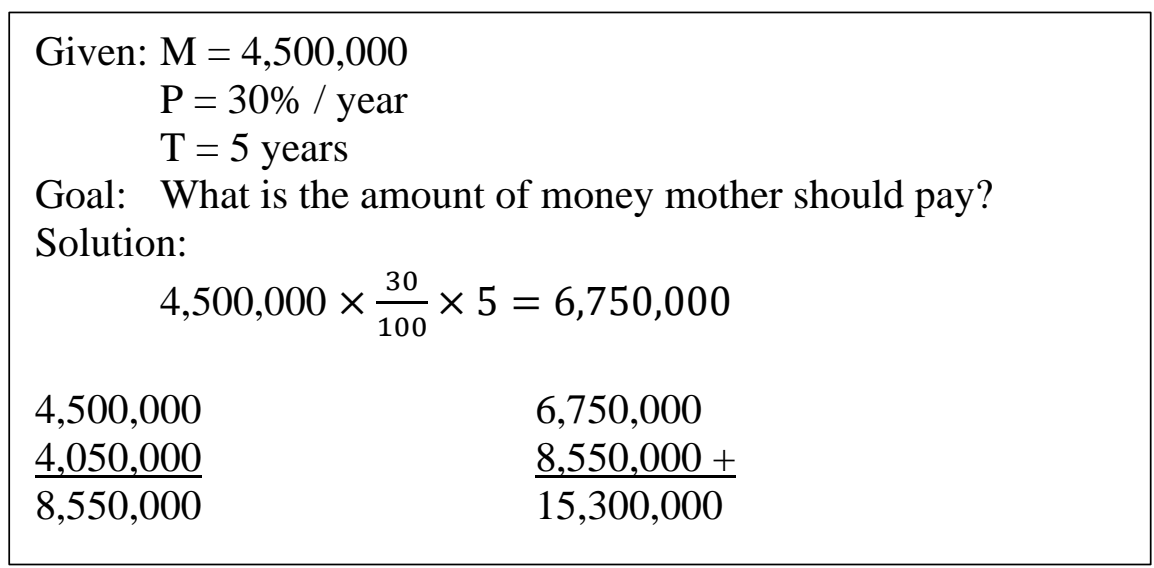

Figure 16. Group 4's answer to Worksheet 2

In Problem 1, most groups have worked by the instruction, used the formula in the correct sequence, and understood it. But there was a group making errors in calculation, as seen in Figure 16.

\section{Determining Net, Gross, and Tare}

The purpose of this activity is to make students understand the concept of net, gross, and tare. Through this activity, students also found strategies in finding the net, gross, and tare in different problems for each group.

\section{PROBLEM 2:}

Mother bought 10 sacks of rice. At each sack, it was written gross $=10 \mathrm{~kg}$ and net $=9.8 \mathrm{~kg}$. What is the tare of each sack?

Figure 17. Problem 2 of Worksheet 2 
Figure 17 shows that students were asked to calculate the weight of each sack if each sack has gross $=10 \mathrm{~kg}$, net $=9.8 \mathrm{~kg}$, and the mother bought ten sacks of rice. The use of this model is another characteristic of RME because it relates to everyday life. Group 1 answered, as presented in Figure 18.

\begin{tabular}{|ll|}
\hline Given & : Gross $10 \mathrm{~kg}$ \\
& Net $9.8 \mathrm{~kg}$ \\
Goal & $:$ Tare? \\
Solution & $:$ Tare $=$ Gross - Net \\
& $\quad=10 \mathrm{~kg}-9.8=0.2 \mathrm{~kg}$. \\
\hline
\end{tabular}

Figure 18. Group 1's answer to Problem 2 Worksheet 2

Group 1 stated that to find tare of each sack, they subtract the net from its gross, and got 0.2 $\mathrm{kg}$. The information is written in sequence and based on the correct formula (See Figure 18). In this problem, most of the group explained in their answer, and all the group provided the right solution.

\section{Determining Discounts}

The material aims to make the students understand the concept of discount as well as a formula to find it. The example of the problem is presented in Figure 19.

\section{PROBLEM 4:}

Rendi wants to buy a cellphone with the price of IDR $1,800,000$. If Rendi gets a discount of $20 \%$, how much he should pay?

Figure 19. Problem 4 of Worksheet 2

In Figure 19, students were asked to find the amount of money Rendi has to pay after getting a discount. Group 1 provided the solution by multiplying the discount rate with the price of the cellphone. Then, they subtracted the amount with the discount, as presented in Figure 20. 


$$
\begin{aligned}
& \text { Solution (Group 2): } \\
& \frac{20}{100} \times 1,800,000=360,000 \text { discount } \\
& =\text { IDR 1,800,000 }- \text { IDR 360,000 } \\
& =\text { IDR 1,440,000 } \\
& \text { (Group 5) } \\
& =\operatorname{IDR} 1,800,000 \times 20 \% \\
& =\operatorname{IDR} 1,800,0 \theta \theta \times \frac{20}{100} \\
& =\text { IDR } 18000 \times 20 \\
& \text { IDR 360,000 } \\
& \begin{array}{ll}
4,500,000 & 6,750,000 \\
4,050,000 & \frac{8,550,000+}{15,300,000}
\end{array}
\end{aligned}
$$

Figure 20. The answer to Problem 4 Worksheet 2

Both Group 2 and Group 5 provided a similar way and got the same answer of IDR $1,440,000$, but, they did not offer any explanation.

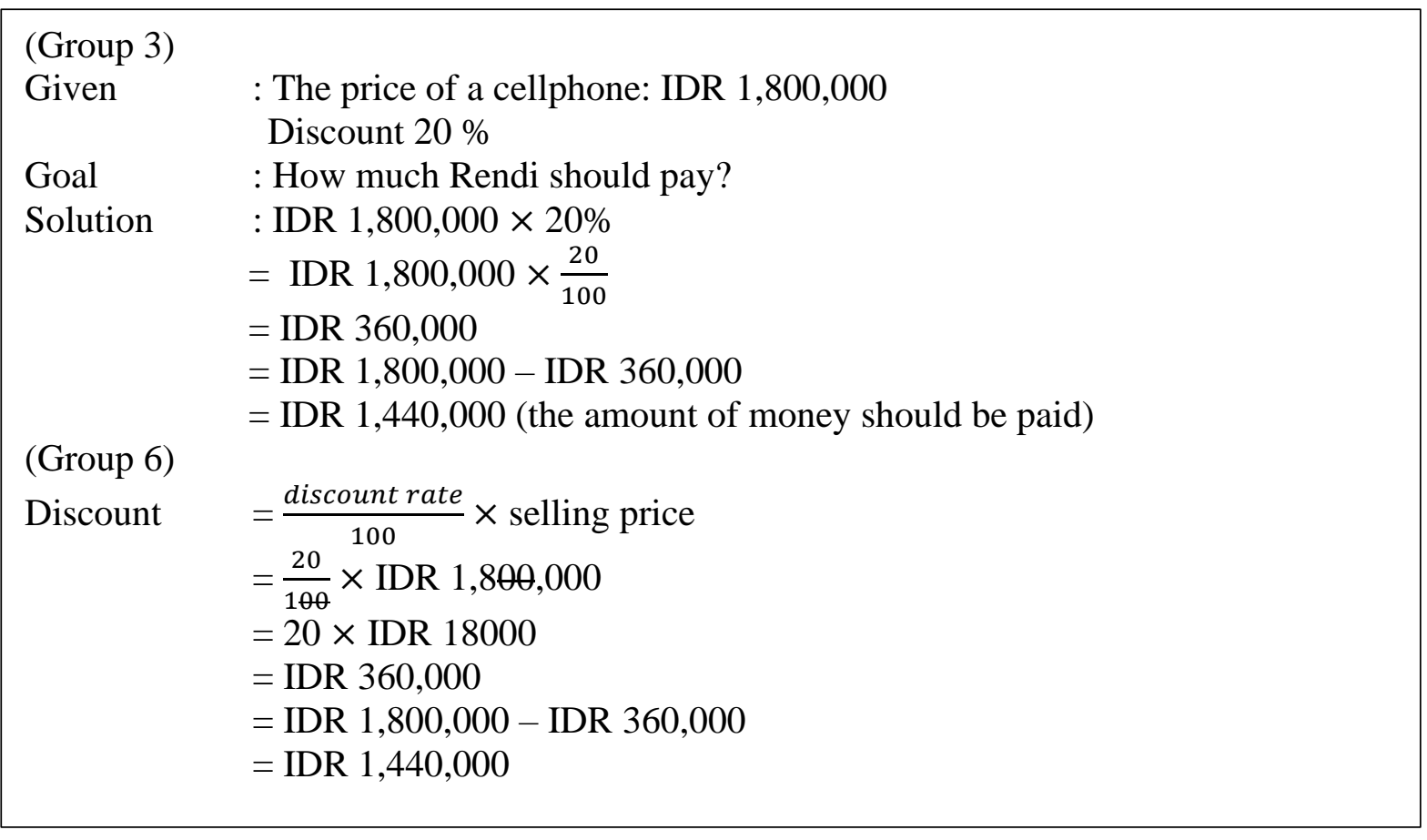

Figure 21. The answer to Group 3 and Group 6 towards Problem 4

Group 3 and 6, similar to others, provided the correct answer, and they also offer a complete explanation as presented in Figure 21. However, there was also Group 4, who did not give any clear statement in their answer, as shown in Figure 22. 


$$
\begin{gathered}
1,800,000 \times \frac{20}{100}=360,000 \\
1,800,000-360=1,440,000
\end{gathered}
$$

Figure 22. Group 4's answer to Problem 4

In this problem, all of the groups have understood the concept to determine the discount and how to solve the related problems.

\section{Determining Tax}

The purpose of this activity is to make students understand about tax and how to determine it. Through this activity, students also find strategies in finding different taxes for each group.

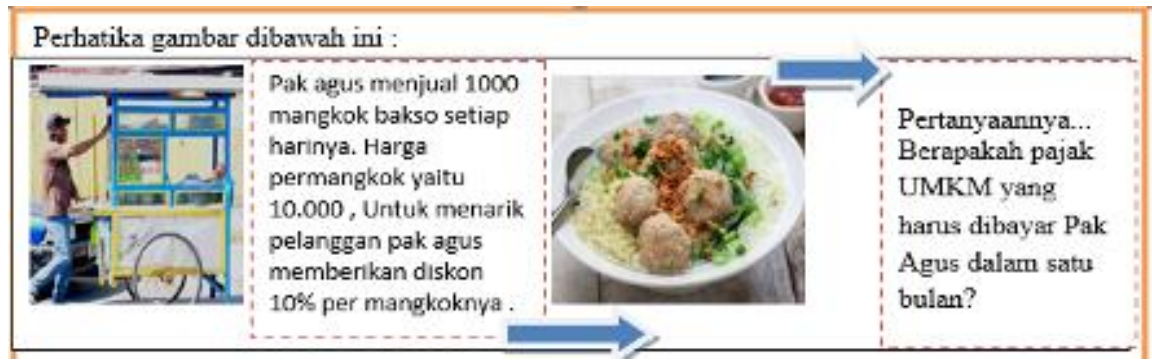

Look at the problems below:

Mr. Agus sells 1000 bowls of meatballs every day. The price for a bowl is IDR 10,000. To attract the customer, Mr Agus gives 10\% discount for each bowl. The question is, how much tax of UMKM does he have to pay in a month?

Figure 23. Problem 5 of Worksheet 2

Figure 23 shows that students were asked to calculate how much UMKM tax (tax for Indonesian micro, small, and medium enterprises) must be paid by Mr. Agus in one month. In Indonesia, the UMKM tax per month is $1 \%$ of the total sales received each month. Group 1 answered Problem 5, as presented in Figure 24.

$$
\begin{aligned}
& =1000 \times 10000 \times \frac{10}{100} \\
& =\frac{100000000}{100} \\
& =1,000,000 \text { (daily income) } \\
& =1,000,000 \times 30 \\
& =30,000,000(\text { income in a month) } \\
& =30,000,000 \times \frac{1}{100} \\
& =300,000(\text { the tax })
\end{aligned}
$$

Figure 24. Group 1's answer to Problem 5 of Worksheet 2 
Group 1 answered by first multiplying the number of meatballs sold in a day with the price and the discount. They claimed it was the daily income. Then it was multiplied by 30 days to get monthly income. Then, $1 \%$ tax applied to get the UMKM tax. This result still has an error, in which Group 1 has not done the process of subtracting the price of meatballs after the discount. Also, Group 2 answered Problem 5, as presented in Figure 25.

$$
\begin{aligned}
& 1000 \times 1,000,000=1,000,000,000 \\
& =1,000,000,000 \times \frac{10}{100} \\
& =\frac{1000,000,000}{100} \\
& =10,000,000 \text { (daily) } \\
& =10,000,000 \times 30 \\
& =300,000,000 \text { (monthly) } \\
& =300,000,000 \times \frac{1}{100} \\
& =3000,000(\text { the tax })
\end{aligned}
$$

Figure 25. Group 2's answer to Problem 5 of Worksheet 2

Group 2 multiplied the number of meatballs sold in a day with 1,000,000, then times $10 \%$. They claimed it as a daily income. The next process was similar to Group 1, with different answers. Finally, they got IDR 3,000,000 as the tax. This result was not correct, either, as they made a similar mistake with Group 1.

Furthermore, Figure 26 shows the result of Group 3. They had a solution. First, they calculated the price of 1 bowl of meatball after discount. Then, it was multiplied by the number of meatballs sold in a day to get the daily income. Second, they found the monthly income by multiplying the daily income with 30 . Then, the $1 \%$ tax was imposed.

Sale $=1000$ bowl a day
Meatball price $=$ IDR $9,000($ after discounted $)$
$\begin{aligned} \text { Daily income } & =1000 \times 9,000=9,000,000 \\ \text { Monthly income } & =9,000,000 \times 30=27,000,000 \\ \text { UMKM tax } & =\text { monthly income } \times \text { tax } \\ & =\text { IDR } 27,000,000 \times 1 \% \\ & =\text { IDR } 270,000\end{aligned}$

Figure 26. Group 3's answer to Problem 5 of Worksheet 2

These solving steps were correct. But Group 3 made an error in the multiplication of $9,000,000 \times 30$. It should be $270,000,000$ but it was written $27,000,000$. Thus, the result was still not correct.

Figure 27 shows the results of answers from Group 5 and 6. Both of the groups have a solution. They first multiplied the price of the meatball with the discount. The result was the 
discount price. Second, they subtracted the unit price by the discount to get the actual cost of 1 bowl after a discount. Third, the exact unit price after a discount was multiplied by the total sales in a day to get the daily income. Fourth, the daily income was multiplied by 30 to get the monthly income. Finally, the monthly income was multiplied by 1 percent to get the amount of tax. They got IDR 2,700,000. The process and the result were correct, but it lacks explanation.

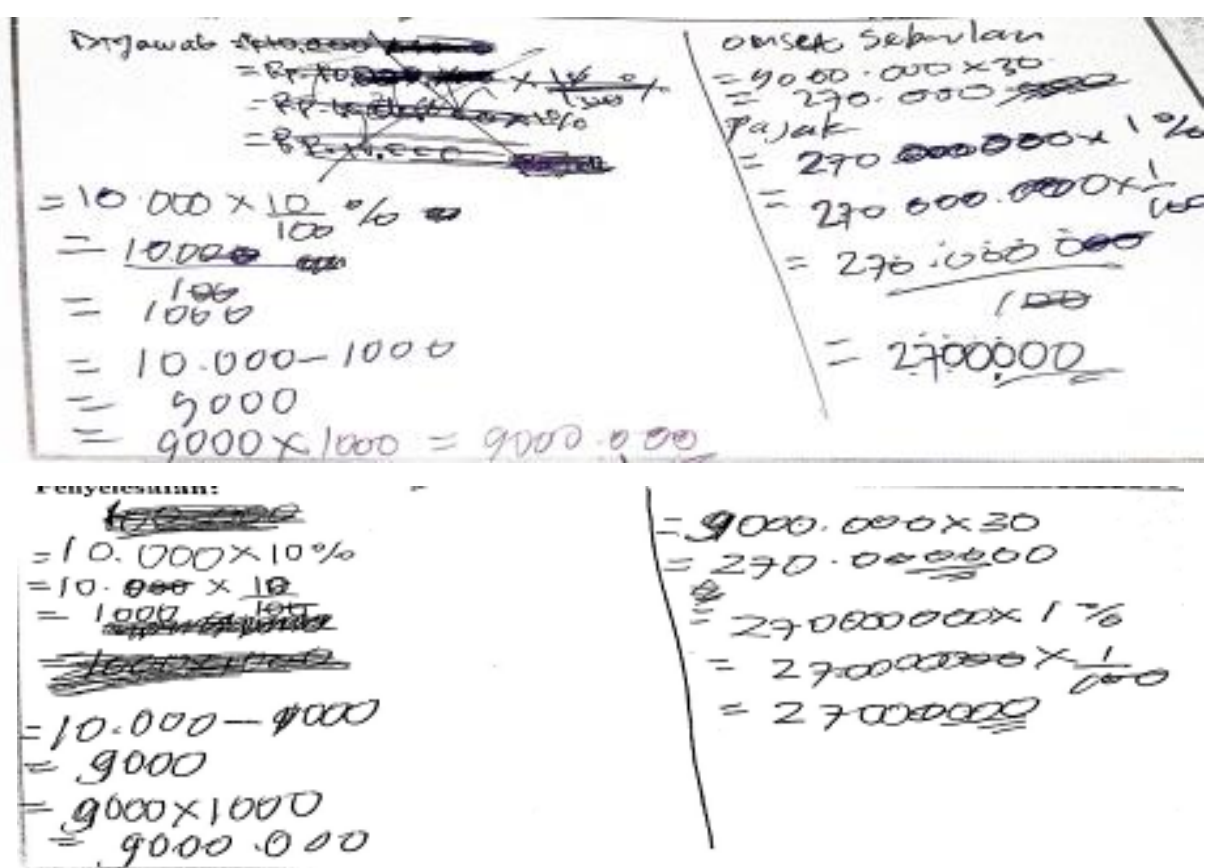

$$
\begin{aligned}
& =10,000 \times \frac{10}{100} \\
& \text { Monthly income } \\
& =\frac{100,00 \theta}{100} \\
& =9,000,000 \times 30 \\
& =1,000 \\
& =10,000-1,000 \\
& =270,000,000 \\
& =9,000 \\
& =9,000 \times 1,000 \\
& =9,000,000 \\
& \begin{array}{c}
=270,000,000 \times 1 \% \\
=\frac{270,000,000}{100} \\
=2,700,000
\end{array}
\end{aligned}
$$

Figure 27. Group 5 and 6's answer to Problem 5 of Worksheet 2

Towards Problem 5 of Worksheet 2, all groups found difficulties in understanding the problem on how to determine the UMKM tax, reviewing their responses. Most of them did not use the given information. Thus, the steps were similar but resulted in a different answer. Only 2 groups had the correct answer as expected by the teacher.

The next activity was the presentation of the group discussion results of Worksheet 2 Problem 1,2, and 5, as shown in Figure 28. The teacher offered to the students who were willing to go forward to write and explain their discussion results, but no student was brave enough to justify their findings. Then, the teacher appointed a male student (S) to present Problem 1, a 
female student $(\mathrm{N})$ to present Problem 2, and another female student (E) to present Problem 5. However, in the middle of the presentation, the bell rang. Thus, the teacher asked them to stop, and the rest of the students gave applause. The teacher discussed together with the written answers on the board and told the next meeting topic.
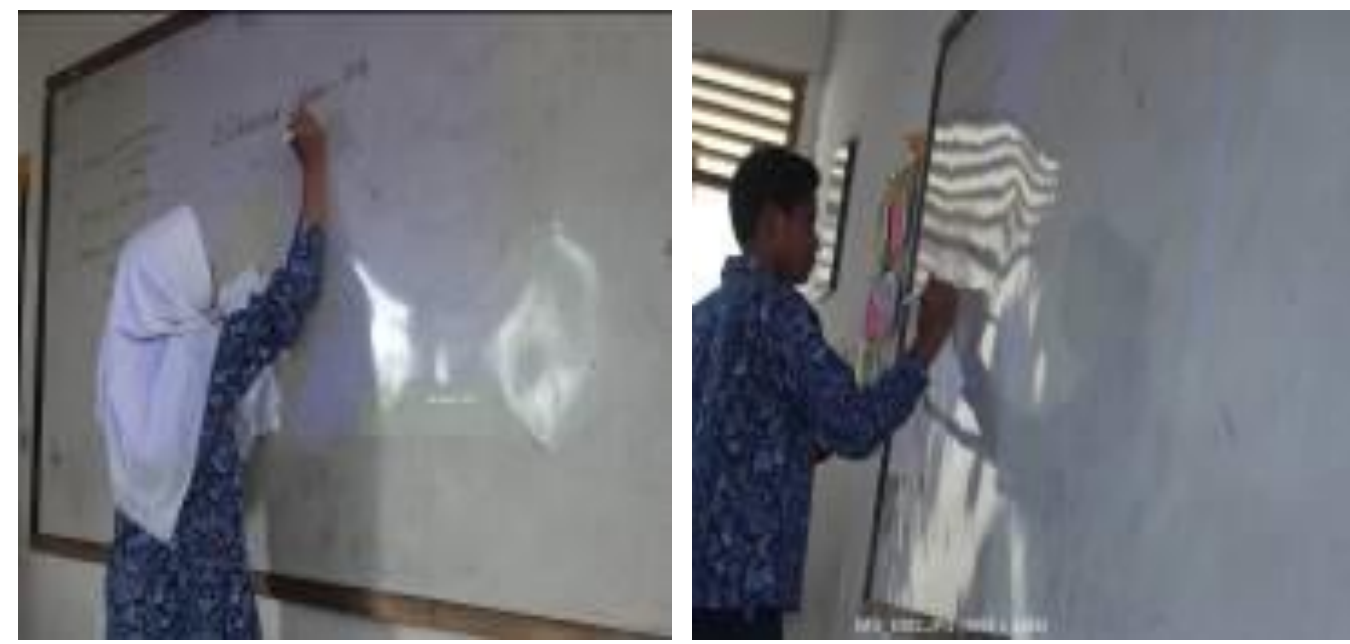

Figure 28. A representative of the groups wrote on the board to start the presentation

Based on the description above, we can see that students still did not carefully understand the instruction within the problems. It made them confused during the problem-solving process. They found difficulties in determining the tax, and then the teacher had to guide them step by step. Though some performed errors in some steps, but the others could complete the worksheet. The students who could complete the worksheet correctly got rewards in the form of "good", "smart", and "very good" predicate from the teacher.

\section{The Third Meeting}

The third meeting started with praying, checking the student attendance, delivering the apperception of the previous materials, and conveying the learning objective. In this meeting, there was only one activity, an evaluation test to measure the students' learning outcome. The teacher delivered the Worksheet 3, consisting of 5 problems that have been discussed in the previous two meetings. Unlike the previous meeting, the students worked individually in 30 minutes. 27 students participated in this test, as shown in Figure 29.

After 30 minutes of working on the worksheet, the students submitted their works to the teacher. The teacher and students ended the learning by praying together. 

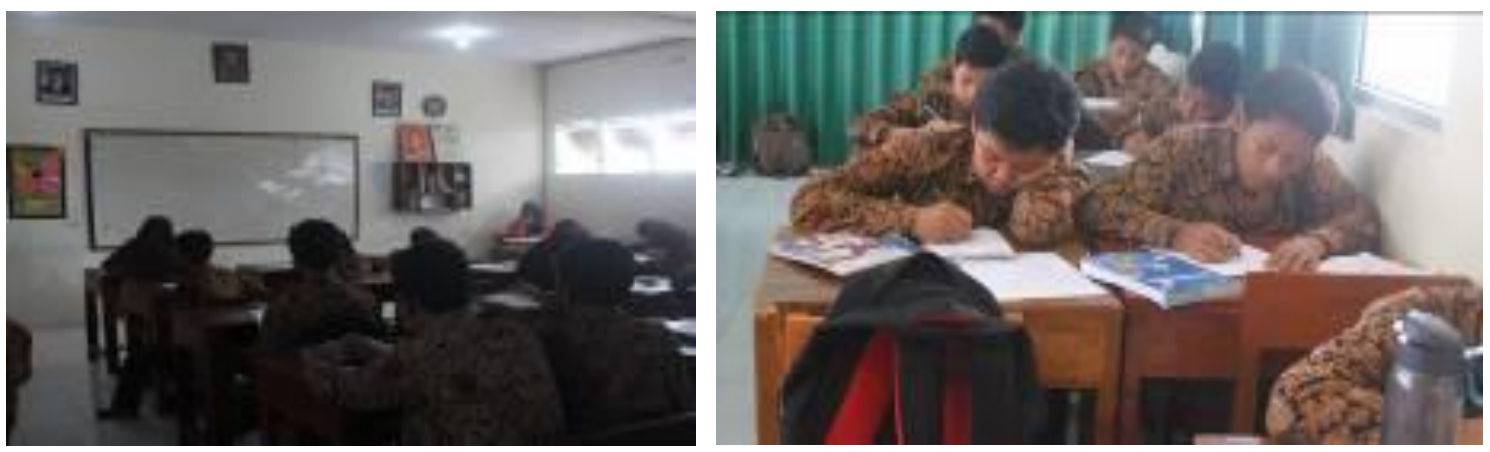

Figure 29. The situation of the students working on Worksheet 3

\section{Analysis of the Test Data}

The test carried out at the third meeting of the 1st of February 2019 aimed to determine the students' learning outcome in social arithmetic. Figure 30 shows the results.

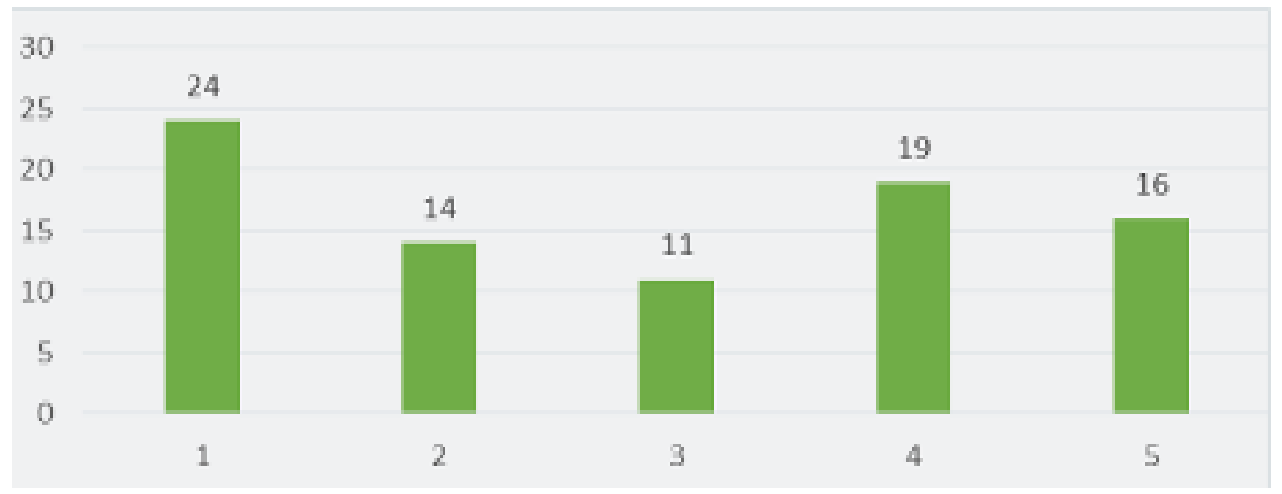

Figure 30. Test Results Data

Figure 30 shows that 24 students could answer Problem 1 correctly, 14 students could answer Problem 2 correctly, 11 students could answer Problem 3 correctly, 19 students could answer Problem 4 correctly, and 16 students could answer Problem 5 correctly. There were some mistakes made by the students in solving the problems. First, students were not careful enough to read the instruction contained in the issues. Second, students were not careful enough to perform multiplication, addition, and subtraction operations. Third, students were lacked focus in working while the time allocation was too short.

\section{The Role of Realistic Mathematics Education}

In the first meeting, the students were introduced to the buying and selling activities through a picture that shows activity in a market. Through the picture, the students knew the nature of buying and selling activities and the results of the activities in the form of profit and 
loss. Further, the students also learned how to determine the amount of profit from the buying and selling activities.

In the second activity, students determined the loss if the buying and selling prices are known. In this activity, students began to understand clearly how the loss can be known through the comparison between buying expenses and selling income. At this point, students can use this knowledge in daily life. This is consistent with Fauzan et al. (2018) and Abadi et al. (2017) whose explained that social arithmetic material has a close relation to everybody's daily life. Thus, it is considered as an essential material.

In the third activity, students were asked to determine the percentage of profit and loss. We taught them to convert the profit or loss in the form of a percentage. This topic is also essential to be used as a comparison for sustainable trading activities in the future (Schaltegger \& Hörisch, 2017).

In the fourth activity, students worked on Worksheet 1 in groups consisting of four students each. Worksheet 1 discussed the first, second, and third activities in the form of problem-solving. In Problem 2, almost all groups have understood the problems given about how to determine the profit and steps that must be taken to solve the problem. The details are presented in Dialogue 2. In the dialogue, we can also see a positive impact on the students' understanding in the form of the students' interest to ask questions related to the problemsolving process. It is relevant to the findings of several research conducted by Laurens et al. (2017), Revina and Leung (2019), and Tanujaya et al. (2017), which suggested that realistic mathematics education approach brings positive and significant effect towards the mathematics understanding. However, in our results, there was one group that was not careful enough to understand the problems' instruction so that there were errors in the work. In Problem 3, all groups have understood the concept to determine the loss if the buying price and selling price are known, and students can find an appropriate way to solve the problems.

In problem 5, which discussed determining the percentage of profit and loss, most groups have understood the given problem. However, there were 2 groups, namely Group 5 and Group 7, who could not meet what the problem wanted. It was due to a lack of accuracy in understanding the problem.

The second meeting consisted of five activities. In this second meeting, we asked the students to pay attention to the pictures in Worksheet 2 about some familiar places in daily life. In the first activity, students were introduced to the first picture that explains the activities usually that y happen in a bank. Most students have understood the general uses of the bank, 
such as savings and loans, but did not understand what is meant by a single interest because they rarely hear about it. Thus, we explained about single interest.

In the second activity, we explained about the net, gross, and tare through picture number 2 about supermarkets, which usually contained net, gross, and tare. In this activity, the students had understood what was meant by net, gross, and tare after we explained it. Further, we continued to the third activity to discuss discounts. In this activity, students know where there are usually discounts. They said that discounts are often in malls, clothing stores, and shoe stores. Then, we explained what is meant by discounts.

In the fourth activity, we asked students about taxes, and it turned out that the students did not understand what was meant by taxes. Then, we immediately explained what tax was and the formula to find the amount of tax. After the students understood all the material in the first activity to the fourth activity, we proceeded to the fifth activity, which was to work on Worksheet 2, which contained problems related to the first activity until the fourth activity.

In the fifth activity, students were divided into 7 groups consisting of four people to complete Worksheet 2. In Worksheet 2, Problem 1 was about determining the single interest. Some groups had worked based on the instructions, such as using a formula in sequence and understanding it. But, Group 2 and Group 4 made some errors in the form of lack of accuracy when working on the problem so that the final results differed significantly from the actual answer. In Problem 2, which asked about determining net, gross, and tare, all groups have understood how to get tare, but some groups did not include information in the answers, so the answers were written very briefly.

Problem 4 was about determining the amount of discount from the buying price of an item. In this problem, all groups could answer correctly, even though there were still a few deficiencies in the inclusion section of the formula or information on the answers made. Problem 5 was about finding the tax rates. Groups 1, 2, and 4 were still trying to determine the steps to look for the UMKM tax amount so that the answers obtained do not match the actual results. In contrast, the Group 3 formula and how to work is correct, but there is an error when multiplying the daily income by the number of days in a month, so the results obtained were wrong. Groups 5 and 6 were considered to have understood the problem because the answers received were appropriate. 


\section{Student Learning Outcomes}

The problems given to students consisted of 5 questions seen in Figure 4, 14, 17, 19, and 23. All of them applied the RME approach. Based on the evaluation test results obtained by checking the students' answers, the average score of students was 81.92. This score was more significant than the standard of a minimum passing grade in SMP Muhammadiyah 1 Mlati, which was 75. Referring to this score, among 27 students who took the test, 25 of them successfully reached the standard. Table 3 explains that the final grades of all VII A students at SMP Muhammadiyah 1 Mlati.

Table 3. Students' learning results

\begin{tabular}{cccc}
\hline Category & Score & Frequency & Percentage \\
\hline Complete & $\geq 75$ & 25 & $92.59 \%$ \\
Not complete & $\leq 75$ & 2 & $7.41 \%$ \\
\hline
\end{tabular}

The final evaluation results showed that $92.59 \%$ of students completed working on the test, with an average score of 81.92 . It shows that the completeness of student learning outcomes has reached the standard of a minimum passing grade in SMP Muhammadiyah 1 Mlati. In other words, there was an increase in the integrity of student learning outcomes. This result is in line with several studies, such as Rahmawati and Amah (2018), Risdiyanti et al. (2019), and Astuti (2019) whose states the average increase student learning outcomes with RME approach, Risdiyanti and Prahmana (2020) whose argued that there is a positive influence and significance of realistic mathematics education (RME) on student learning outcomes, and also Farida, Hartatiana, and Joemsittiprasert (2019) whose use the Realistic Mathematics Education (RME) in improving mathematical analogical ability and habits of mind.

\section{Conclusions}

The implementation of learning innovations in social arithmetic material using the RME approach in SMP Muhammadiyah 1 Mlati was done by the use of context daily activities, which were close to the students as the starting point of learning a positive contribution to student learning outcomes. There are three significant contexts used during teaching and learning activities, namely buying and selling activities in the market to discuss profit and loss, activities in the bank to discuss single interest, simulation of activities in shopping centers to explain net, gross, tare, and discounts, as well as activities in tax office to simulate tax material. The results of the implementation of the learning activities were evaluated at the final meeting of the study. The last meeting was an evaluation of learning using a test instrument against all 
material that has been taught to determine the successful application of a realistic mathematics education approach (PMR) to student learning outcomes. The results showed that social arithmetic learning using RME approach in the form of word problems could reach an average value of 81.92 of 27 students and 25 students among them had scores above the standard of minimum passing grade which means that $92.59 \%$ of the total of students in the above standard score. Lastly, this result could be used as a reason for further research by comparing the results of the study using the RME and conventional approaches.

\section{Acknowledgments}

The author would like to thank Universitas Ahmad Dahlan that supported this research. Furthermore, thanks to all participated students and teachers for their participation in this study

\section{References}

Abadi, M. K., Pujiastuti, H., \& Assaat, L. D. (2017). Development of teaching materials based interactive scientific approach towards the concept of social arithmetic for junior high school students. Journal of Physics: Conference Series, 812(1), 012015. https://doi.org/10.1088/1742-6596/812/1/012015.

Albadi, N. M., Harkins, J., \& O'Toole, J. M. (2019). Recent reforms in Saudi secondary science education: Teacher and student perceptions of grade 10 physics. International Journal of Science and Mathematics Education, 17(4), 701-721. https://doi.org/10.1007/s10763-0189881-3.

Astuti, N. R. (2019). The effect of RME on mathematics learning outcomes viewed mathematic communication skills. International Journal of Educational Research Review, 5(1), 43-53. https://doi.org/10.24331/ijere.650864.

Chao, T., Chen, J., Star, J. R., \& Dede, C. (2016). Using digital resources for motivation and engagement in learning mathematics: Reflections from teachers and students. Digital Experiences in Mathematics Education, 2(3), 253-277. https://doi.org/10.1007/s40751016-0024-6.

Fägerstam, E., \& Grothérus, A. (2018). Secondary school students' experience of outdoor learning: A Swedish case study. Education, 138(4), 378-392.

Farida, Hartatiana, \& Joemsittiprasert, W. (2019). The use of Realistic Mathematics Education (RME) in improving mathematical analogical ability and habits of mind. Al-Jabar: Jurnal Pendidikan Matematika, 10(2), 175-186. https://doi.org/10.24042/ajpm.v10i2.3540.

Fauzan, A., Armiati, A., \& Ceria, C. (2018). A learning trajectory for teaching social arithmetic using RME approach. IOP Conference Series: Materials Science and Engineering, 335(1), 012121. https://doi.org/10.1088/1757-899X/335/1/012121.

Fauzan, A., Plomp, T., \& Gravemeijer, K. P. E. (2013). The development of an RME-based geometrycourse for Indonesian Primary schools. In T. Plomp, \& N. Nieveen (Eds.), Educational design research - Part B. Illustrative cases (pp. 159-178). SLO: Netherlands institute for curriculum development.

Gravemeijer, K. P. E. (1994). Developing realistic mathematics education. Utrecht: Freudenthal Institute. 
Gravemeijer, K. P. E. (1999). Developmental research: Fostering a dialectic relation between theory and practice. In J. Anghileri (Ed.), Principles and practice in arithmetic teaching (pp. 147161). London: Open University Press.

Jupri, A., \& Drijvers, P. H. M. (2016). Student difficulties in mathematizing word problems in algebra. Eurasia Journal of Mathematics, Science and Technology Education, 12(9), 24812502. https://doi.org/10.12973/eurasia.2016.1299a.

Kempert, S., Saalbach, H., \& Hardy, I. (2011). Cognitive benefits and costs of bilingualism in elementary school students: The case of mathematical word problems. Journal of educational psychology, 103(3), 547-561. https://doi.org/10.1037/a0023619.

Kowiyah, Mulyawati, I., \& Umam, K. (2019). Conceptual understanding and mathematical representation analysis of realistic mathematics education based on personality types. $\mathrm{Al}$ Jabar: Jurnal Pendidikan 201-210. https://doi.org/10.24042/ajpm.v10i2.4605.

Kurnia, I. A., \& Retnowati, E. (2019, March). What is erroneous worked example and how is it looks like in social arithmetic?. Journal of Physics: Conference Series, 1200(1), 012020. https://doi.org/10.1088/1742-6596/1200/1/012020.

Laurens, T., Batlolona, F. A., Batlolona, J. R., \& Leasa, M. (2017). How does realistic mathematics education (RME) improve students' mathematics cognitive achievement?. Eurasia Journal of Mathematics, Science and Technology Education, 14(2), 569-578. https://doi.org/10.12973/ejmste/76959.

Liskala, T., Vauras, M., Lehtinen, E., \& Salonen, P. (2011). Socially shared metacognition of dyads of pupils in collaborative mathematical problem-solving processes. Learning and instruction, 21(3), 379-393. https://doi.org/10.1016/j.learninstruc.2010.05.002.

Mundia, L. (2017). The assessment of math learning difficulties in a primary grade-4 child with high support needs: Mixed methods approach. International Electronic Journal of Elementary Education, 4(2), 347-366.

Rahmawati, N. K., \& Amah. (2018). The differences of the student learning outcome using realistic mathematics learning approaches (PMR) and contextual learning approaches (CTL) on the sets material.Al-Jabar: Jurnal Pendidikan Matematika,9(1), 63-71. https://doi.org/10.24042/ajpm.v9i1.2243.

Retnawati, H., Kartowagiran, B., Arlinwibowo, J., \& Sulistyaningsih, E. (2017). Why are the mathematics national examination items difficult and what is teachers' strategy to overcome It?. International Journal of Instruction, 10(3), 257-276. https://doi.org/10.12973/iji.2017.10317a.

Revina, S., \& Leung, F. K. S. (2019). How the same flowers grow in different Soils? The implementation of realistic mathematics education in Utrecht and Jakarta classrooms. International Journal of Science and Mathematics Education, 17(3), 565-589. https://doi.org/10.1007/s10763-018-9883-1.

Risdiyanti, I., \& Prahmana, R. C. I. (2020). The learning trajectory of number pattern learning using "Barathayudha" war stories and Uno Stacko. Journal on Mathematics Education, 11(1), 157166. https://doi.org/10.22342/jme.11.1.10225.157-166.

Risdiyanti, I., Prahmana, R. C. I., \& Shahrill, M. (2019). The learning trajectory of social arithmetic using an Indonesian traditional game. Elementary Education Online, 18(4), 2094-2108. https://doi.org/10.17051/ilkonline.2019.639439.

Schaltegger, S., \& Hörisch, J. (2017). In search of the dominant rationale in sustainability management: legitimacy-or profit-seeking?. Journal of Business Ethics, 145(2), 259-276. https://doi.org/10.1007/s10551-015-2854-3. 
Tanujaya, B., Prahmana, R. C. I., \& Mumu, J. (2017). Mathematics instruction, problems, challenges, and opportunities: A case study in Manokwari regency, Indonesia. World Transactions on Engineering and Technology Education, 15(3), 287-291.

Vilianti, Y., Pratama, F., \& Mampouw, H. (2018). Description of the ability of social arithmetical stories by study problems by students VIII SMP reviewed from the Polya stage. International Journal of Active Learning, 3(1), 23-32. 